\title{
Article \\ Climate Change Effects on Trophic Interactions of Bark Beetles in Inner Alpine Scots Pine Forests
}

\author{
Beat Wermelinger ${ }^{1, *(\mathbb{D}}$, Andreas Rigling ${ }^{2,3}$, Doris Schneider Mathis ${ }^{1}$, Marc Kenis ${ }^{4}$ and Martin M. Gossner ${ }^{1,3}(\mathbb{D}$ \\ 1 Swiss Federal Institute for Forest, Snow and Landscape Research WSL, Forest Entomology, \\ 8903 Birmensdorf, Switzerland; doris.schneider@wsl.ch (D.S.M.); martin.gossner@wsl.ch (M.M.G.) \\ 2 Swiss Federal Institute for Forest, Snow and Landscape Research WSL, Forest Dynamics, \\ 8903 Birmensdorf, Switzerland; andreas.rigling@wsl.ch \\ 3 ETH Zurich, Institute of Terrestrial Ecosystems, 8092 Zurich, Switzerland \\ 4 CABI Europe-Switzerland, 2800 Delémont, Switzerland; m.kenis@cabi.org \\ * Correspondence: beat.wermelinger@wsl.ch
}

check for

updates

Citation: Wermelinger, B.; Rigling, A.; Schneider Mathis, D.; Kenis, M.; Gossner, M.M. Climate Change Effects on Trophic Interactions of Bark Beetles in Inner Alpine Scots Pine

Forests. Forests 2021, 12, 136. https://doi.org/10.3390/f12020136

Received: 4 January 2021

Accepted: 21 January 2021

Published: 25 January 2021

Publisher's Note: MDPI stays neutral with regard to jurisdictional claims in published maps and institutional affiliations.

Copyright: (c) 2021 by the authors. Licensee MDPI, Basel, Switzerland. This article is an open access article distributed under the terms and conditions of the Creative Commons Attribution (CC BY) license (https:// creativecommons.org/licenses/by/ $4.0 /)$.

\begin{abstract}
Increased tree mortality has become a widespread phenomenon and is largely attributed to climate change. Little field research has addressed the complex interactions between trees, herbivores, and their natural enemies as affected by temperature. We recorded the densities of bark insects and their natural enemies emerging from felled trees in Scots pine forests at 17 study sites along 6 elevation gradients encompassing different temperature ranges in 3 regions in Switzerland and Italy. We additionally measured tree resin defense at different elevations. The density of aggressive bark beetles decreased with increasing temperatures while that of non-aggressive species did not respond to temperature. Contrasting patterns were also found for natural enemies, with the densities of most predatory taxa decreasing with increasing temperature whereas densities of parasitoids increased. Consequently, bark beetle mortality by predators decreased and that by parasitoids increased with temperature. Exudation of resin increased with temperature. As the number of resin ducts did not change with temperature, this is assumed a physical effect of reduced viscosity. Despite lower densities of aggressive bark beetles and improved tree resin flow under higher temperatures, the currently experienced drought-induced reduction in tree vigor is likely to increase tree mortality under the ongoing climate warming.
\end{abstract}

Keywords: elevation gradient; natural enemies; parasitoids; predators; Scolytinae; tree defense

\section{Introduction}

In the past few decades, increased mortality of trees has been observed worldwide, becoming manifest on all continents and in various climates [1-3]. This is mainly attributed to an increased frequency, duration, and severity of drought and heat stress brought about by climate change. Increased tree mortality may be caused by temperature-mediated changes in tree physiology [4], increased frequencies of windstorms or wildfires, lethal infestation by insects and pathogens, or a combination thereof $[5,6]$. In particular, mortality in conifers is often related to bark beetles or other phloeophagous (phloem feeding) species (e.g., [7-10]), which, in combination with associated fungi, interrupt the transport of water and photosynthates [11,12]. Bark beetle-mediated tree mortality is the result of complex interactions between trophic levels: (i) number of available trees and their susceptibility, (ii) population size, colonization density, and reproduction of bark beetles, and (iii) the regulation of these pests by natural enemies (e.g., [4,13]). These multifaceted, trophic interactions between host tree, phloem feeders, and their natural enemies are intricate per se and difficult to analyze. Climate change is likely to alter these interactions and thus adds additional complexity to the system. Such multitrophic interactions have been identified as important gaps in process-based ecosystem models $[6,14,15]$. 
Global warming can affect all of the three trophic levels involved. Host plants are clearly affected by increasing temperatures and more pronounced drought periods. According to the growth-defense tradeoff hypothesis, plants generally prioritize resource allocation to defense rather than growth in cases of resource restrictions [15-17]. For instance, plants suffering from moderate stress caused e.g., by a shortage of light or nutrients or by herbivory generally direct more plant carbon to defense mechanisms than unstressed ones $[18,19]$. However, severely drought-stressed pines have been shown to produce less defensive resin than moderately or non-stressed ones [20,21]. Resin can act both mechanically, by flushing out penetrating bark beetles or miring them in the sticky fluid, and toxically, by killing the colonizing beetles and their broods [12,19].

Successful bark beetle colonization largely depends on the interactions between beetle population density and the defensive capacity of the host trees [22,23]. Temperature is one of the most important factors directly driving herbivorous insects by affecting their development, allowing for additional generations per year, increasing their egg production, and altering their phenology and winter mortality [24-29].

With global warming, predators and parasitoids of herbivorous insects will most likely develop faster and produce more offspring as well. However, it remains unclear how this will affect mortality of their prey and hosts [14]. A critical issue is the possible disruption of phenological synchrony. For example, if the larval instar of a bark beetle required by a specialized parasitoid becomes available before or after the main flight period of this parasitoid, the effect of the parasitoid on bark beetle populations will decline. Thus, climate change might increase herbivore mortality by predators, due to increased predator offspring production, but simultaneously decrease herbivore mortality by parasitoids because of a phenological mismatch [30].

These manifold interactions and dependencies of multitrophic systems require a holistic approach, but at the same time, such studies are extremely complex, even more so when climate change effects are considered [14,31]. For these reasons, effects of climate change have been routinely studied at a single factor level, such as effects of temperature or drought on trees or insects (e.g., [29,32-34]). The few existing studies on trophic interactions have mostly been carried out in model ecosystems with young, easily-manipulated host plants (e.g., $[35,36])$, because manipulating abiotic factors in mature forests to mimic global warming is extremely laborious and costly $[37,38]$. As an alternative approach, elevation gradients can be used, which provide a natural range of temperatures in an otherwise similar environment. While this approach has occasionally been applied in plant or insect population studies [39-41], it has rarely been deployed to investigate multitrophic interactions under continuing climate change [42]. A single study on bark beetle attack risk was carried out with Dendroctonus ponderosae Hopkins, its competitors, and a predatory beetle (Thanasimus undatulus Say) in a very small range of elevations and across stands of varying tree composition [43]. Thus, elevation effects could not be separated from stand-level effects in that study.

We studied multitrophic interactions in Scots pine (Pinus sylvestris L.) forests in three subalpine valleys in Europe along six elevation (temperature) gradients. Each spanned $700 \mathrm{~m}$ and showed temperature differences of $3-5{ }^{\circ} \mathrm{C}$, but was characterized by forests of comparable tree species composition and forest structural attributes. We evaluated the responses of population densities of bark beetles and their mortality by natural insect enemies as well as host tree resin defense to increasing temperatures. We hypothesized that with increasing temperatures from high to low elevations: (i) bark beetle densities increase, (ii) predator and parasitoid-induced bark beetle mortality increases because of higher natural enemy densities (assuming that parasitoids have not yet experienced phenological mismatch at the warmest sites), and (iii) tree resin flow increases because viscosity is lower. 


\section{Materials and Methods}

\subsection{Sites}

Elevation gradients were established in three central European inner Alpine valleys (regions) with a rather continental climate: the Rhine Valley near Chur (Grisons, Switzerland), the central Valais (Switzerland), and the Aosta Valley (Italy) (Table 1). In each of the three regions, two locations were selected with slopes of Scots pine forest, with comparable composition in terms of structure and admixed tree species, from the bottom of the valley up to the subalpine zone. In the Valais and Aosta regions, the two locations had north or south aspects. In the Grison region, only two south aspects were available. Along each gradient, three forest sites (stands) at different elevations were selected, with the exception of one gradient in the Aosta region where no low-elevation site with a comparable pine forest was available (see Table 1). This amounts to a total of 17 sites. All stands were dominated by Scots pine with various admixtures of Norway spruce (Picea abies [L.] H. Karst.), European larch (Larix decidua Mill.) and, at one site, European beech (Fagus sylvatica L.). In all regions, the populations of potential phloeophagous pests were at endemic levels, i.e., there were no outbreaks before or during the time of the study.

At each site, two temperature loggers (iButton ${ }^{\circledR}$, Maxim Integrated, San Jose, CA, USA) were attached on the shaded north faces of two trees. They recorded hourly temperatures from which mean summer (April to September) and winter (December to February) temperatures were calculated (Table 1$)$.

\subsection{Insect Sampling}

At each site and in each of the two sampling years, four Scots pine trees of 15-39 cm $\mathrm{dbh}$ and a minimum distance of approx. $30 \mathrm{~m}$ apart were randomly selected (Table 1). The 132 trees (one site was sampled in one year only) were felled between October and December preceding the sampling years so the stems could moderately desiccate during winter to become attractive for wood insects. No additional lures were used. After the trees were colonized by insects in the following spring, two $80-\mathrm{cm}$-bolts of $12-35 \mathrm{~cm}$ diameter were cut from the stem base and the crown base of each tree in June, along with two 80 -cm-long pieces of thick branches from each crown. This timing ensured that species swarming later in spring were captured and prevented the progeny of early fliers from emerging before the sampling. To account for the longer insect development times at higher elevations, bolt collection was staggered over time: those from the lower and middle sites were collected in early June and those from the top sites at the end of June. The 264 colonized bolts and 264 branches were then transported to the lab and exposed for two years in emergence traps placed in a greenhouse with roughly ambient temperatures. The emergence traps were constructed from metal cabinets, with tubes at both the bottom and the top (Figure S1). The tubes ended in semi-transparent collector boxes containing water, detergent, and fungicide. The collectors with the emerged insects were emptied at regular intervals and the captured insects were stored in 70\% ethanol. The collected 140,000 insects were first sorted to a higher taxonomic level, and then all Coleoptera and those dipteran and hymenopteran families that include bark beetle predators or parasitoids (according to [44]) were identified to the species level. Insect counts were converted to densities $\left(\mathrm{m}^{-2}\right)$ calculated from diameter and length of the bolts. 


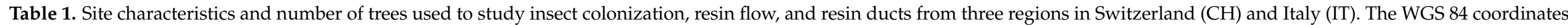
refer to the site at the middle elevation level. (Pin = Scots pine, $\mathrm{Spr}=$ Norway spruce, Lar = European larch, Bee = European beech).

\begin{tabular}{|c|c|c|c|c|c|c|c|c|c|c|c|}
\hline Region & $\begin{array}{c}\text { Sampling } \\
\text { Years }\end{array}$ & Location & $\begin{array}{l}\text { Slope } \\
\text { Aspect }\end{array}$ & $\begin{array}{c}\text { Elevation } \\
\text { [m a.s.1.] } \\
\text { (=Site) }\end{array}$ & Stand & $\begin{array}{l}\text { \# Trees for } \\
\text { Coloniza- } \\
\text { tion }\end{array}$ & $\begin{array}{c}\text { TREE } \\
\text { Height [m] }\end{array}$ & $\begin{array}{l}\text { \# Trees for } \\
\text { Resin Flow }\end{array}$ & $\begin{array}{l}\text { \# Trees for } \\
\text { Resin Ducts }\end{array}$ & $\begin{array}{c}\text { Mean } \\
\text { Summer } \\
\text { Temp. }\left[{ }^{\circ} \mathrm{C}\right]\end{array}$ & $\begin{array}{c}\text { Mean } \\
\text { Winter } \\
\text { Temp. }\left[{ }^{\circ} \mathrm{C}\right]\end{array}$ \\
\hline \multirow[t]{6}{*}{ Valais $(\mathrm{CH})$} & \multirow[t]{6}{*}{ 2010, 2011} & \multirow{3}{*}{$\begin{array}{c}\text { Salgesch } \\
46.3299 \\
7.5866\end{array}$} & \multirow[t]{3}{*}{ South } & 900 & Pin,Spr & 8 & $11.1 \pm 2.57$ & 16 & - & 15.6 & -0.4 \\
\hline & & & & 1200 & Pin,Spr & 8 & $14.6 \pm 2.73$ & - & - & 13.7 & -0.6 \\
\hline & & & & 1600 & Pin,Spr & 8 & $16.6 \pm 1.66$ & 14 & - & 11.3 & -2.8 \\
\hline & & \multirow{3}{*}{$\begin{array}{c}\text { Visp } \\
46.2930 \\
7.8101\end{array}$} & \multirow[t]{3}{*}{ North } & 900 & Pin,Lar,Spr & 8 & $14.3 \pm 2.74$ & 16 & 10 & 15.5 & -0.2 \\
\hline & & & & 1200 & Pin,Lar,Spr & 8 & $16.9 \pm 2.83$ & - & - & 14.0 & -1.2 \\
\hline & & & & 1500 & Pin,Spr & 8 & $15.5 \pm 1.61$ & 15 & 10 & 11.5 & -3.1 \\
\hline \multirow[t]{5}{*}{ Grisons $(\mathrm{CH})$} & \multirow[t]{5}{*}{ 2011, 2012} & \multirow{3}{*}{$\begin{array}{c}\text { Scharans } \\
46.7204 \\
9.4715\end{array}$} & \multirow[t]{3}{*}{ South } & 900 & Pin,Spr & $4^{\mathrm{a}}$ & $9.1 \pm 2.43$ & 12 & - & 14.3 & -0.3 \\
\hline & & & & 1200 & Pin,Spr & 8 & $17.3 \pm 2.93$ & - & - & 13.2 & -1.1 \\
\hline & & & & 1700 & Pin,Spr & 8 & $16.9 \pm 2.74$ & 11 & - & 9.2 & -3.3 \\
\hline & & \multirow{2}{*}{$\begin{array}{c}\text { Felsberg } \\
46.8584 \\
9.4722\end{array}$} & \multirow[t]{2}{*}{ South } & 800 & Pin,Bee,Spr & 8 & $14.1 \pm 1.27$ & 12 & 10 & 14.9 & 1.5 \\
\hline & & & & 1300 & Pin,Spr,Lar & 8 & $16.7 \pm 2.16$ & - & - & 12.1 & -0.8 \\
\hline \multirow[t]{6}{*}{ Aosta (IT) } & \multirow[t]{6}{*}{2010,2011} & \multirow{3}{*}{$\begin{array}{c}\text { Sarre } \\
45.7319, \\
7.2472\end{array}$} & \multirow[t]{3}{*}{ South } & 900 & NA & & & & & & \\
\hline & & & & 1200 & Pin & 8 & $16.7 \pm 2.19$ & 15 & - & 13.8 & -1.9 \\
\hline & & & & 1600 & Pin,Lar,Spr & 8 & $16.4 \pm 2.06$ & 15 & - & 11.5 & -3.2 \\
\hline & & \multirow{3}{*}{$\begin{array}{c}\text { Aymavilles } \\
45.6861 \\
7.2416\end{array}$} & \multirow[t]{3}{*}{ North } & 900 & Spr,Pin & 8 & $8.6 \pm 1.25$ & 17 & - & 15.8 & -0.2 \\
\hline & & & & 1200 & Spr,Pin & 8 & $11.8 \pm 2.73$ & - & - & 13.9 & -1.7 \\
\hline & & & & 1500 & Spr,Pin,Lar & 8 & $12.8 \pm 2.13$ & 16 & - & 12.5 & -2.4 \\
\hline
\end{tabular}

${ }^{a}$ in 2011 only. 


\subsection{Insect Classification and Mortality Assessment}

In addition to taxonomy, insects were classified according to their significance: (i) 'aggressive' bark beetles (Coleoptera: Scolytinae): Ips spp., Pityogenes spp., Tomicus spp.—with aggressiveness ('primary' vs. 'secondary' pests) categorized according their preferred tree resistance [45]; (ii) 'non-aggressive' bark beetles: Crypturgus spp., Dryocoetes autographus (Ratz.), Hylurgops palliatus (Gyll.)., Orthotomicus spp., Pityophthorus pityographus (Ratz.); (iii) predators: Coleoptera: Cleridae, Diptera: Dolichopodidae, Lonchaeidae; and (iv) parasitoids: Hymenoptera: Braconidae, Pteromalidae, Eupelmidae. The buprestid Phaenops cyanea (F.) is considered an aggressive species, the weevil Pissodes pini (L.) a non-aggressive. Predators and parasitoids combined make up total natural enemies. To estimate the mortality rate of phloem feeders imposed by predators, the consumption rates of individual predatory taxa were used [44]. The number of prey consumed by each individual during its development was multiplied by the abundance of the respective taxon. In this way, the total number of prey eaten by predators was obtained and, together with the number of parasitoids ( 1 parasitoid larva kills 1 host larva, all being solitary parasitoids), the total number of phloem feeders killed by natural enemies and thus the phloem feeders' mortality rate were assessed for each tree.

\subsection{Resin Collection}

Exuding resin was collected as a measure of the constitutive resistance of host trees [12]. In 2011, resin flow was recorded for 12-17 trees at both the bottom and top sites of each elevation gradient, resulting in a total of 170 trees (Sarre: middle instead of bottom; cf. Table 1). For this purpose, two $13 \mathrm{~mm}$ holes were punched into the bark at breast height on the north and south expositions of each tree stem. A plastic adapter (sampler) (Missoula Technology Development Center; [46]) was firmly attached to the hole to make sure that all exuding resin was directed into the sampler. Preweighed plastic tubes screwed into the thread of the samplers collected the resin. The tubes were removed after $24 \mathrm{~h}$, sealed and stored in a cooling box, and then transported to the lab. They were reweighed in order to gravimetrically obtain the resin exuded during $24 \mathrm{~h}$.

\subsection{Resin Duct Density}

At the bottom and top sites of the south slope in Felsberg (Grisons) and north slope in Visp (Valais), stem cores (5-8 cm long, $1 \mathrm{~cm}$ in diameter) were taken by means of an increment borer. At each site, 10 trees were cored on both the north and south expositions of each stem, resulting in a total of 40 trees and 80 tree cores. From each core, tangential thin sections of 30-40 $\mu \mathrm{m}$ were made from the inner and outer phloem, as well as from the outer sapwood. They were stained with Astra blue and Safranin, dehydrated with alcohol and embedded in Canada balsam [47]. The blue-stained resin ducts located in the center of the rays were counted in four randomly selected areas of the thin sections (in total 960 samples) in a defined field of vision $\left(3.556 \mathrm{~mm}^{2}\right)$ under a microscope at $4 \times$ magnification (Figure S2).

\subsection{Analyses}

For analysis, the emergence data from the two years were pooled. All analyses were conducted using $\mathrm{R}$ version 3.6.0 [48]. To test for effects of temperature on the densities of functional groups or single species and on species richness, linear mixed effects models were implemented, with region (Grisons, Valais, Aosta) and temperature as fixed factors and site as random factor, using the lme function in the package 'nlme' [49]. Densities were log-transformed to reach model assumptions. Assumptions of normal distribution and homoscedasticity of the residuals were tested using diagnostic plots. To test the effects of species richness of natural enemies, region and temperature on the natural enemy/bark beetle ratio, a generalized mixed effects model was implemented, with cbind (natural enemies, Scolytinae) as the response variable, using the function glmer in the package 'Ime4' [50]. To assess the effects on bark beetle mortality, beta-regression analysis (family 
= beta_family with logit link function) based on a generalized linear mixed model was applied with a template model builder, using the glmmTMB function in the package 'glmmTMB' [51]. In both analyses, site was included as a random factor. For testing resin flows and resin duct densities, linear mixed effects models were implemented, with region and temperature as well as the exposition of the resin samplers on the stem $(\mathrm{N}, \mathrm{S})$ as fixed factors and tree within plot as random factor, using the lme function in the package 'nlme' [49]. Results are presented as values from an analysis of deviance table (Type II Wald chi-square tests) conducted with the package 'car' [52].

The effects of temperature on major groups (aggressive and non-aggressive bark beetles, natural enemies) and resin flow are presented as effect plots with back-transformed response values using the predictorEffect function in the package 'effects' [52,53]. The analyses were done with both mean summer temperatures and mean winter temperatures of the respective elevation levels (Table 1). Since the results of the two temperature groupings were equivalent (Table S1), only the results using the summer temperatures are presented in the Results section. A complete list of the statistical results is given in Table S1.

\section{Results}

\subsection{Densities of Emerged Insects}

The vast majority ( $83 \%$ ) of the more than 140,000 individuals emerging from the Scots pine bolts and branches were bark beetles (Scolytinae), in particular Tomicus minor (Hartig) (for a species list see Table S2). Among bark beetles, the densities of the aggressive species decreased with increasing temperature (Figure 1a; $p<0.05$; all statistical details are listed in Table S1). Aggressive species were dominated at the higher sites by Ips acuminatus (Gyll.) and Tomicus piniperda (L.). Ips acuminatus had on average six times higher densities at the highest sites than at the lowest ones but there was no significant response to temperature (Figure 1aa). The density of the most abundant bark beetle species, i.e., T. minor, was unaffected by temperature, but the congener $\mathrm{T}$. piniperda decreased in density with increasing temperature (negative $t$-value in Figure 1aa). Pityogenes species were not affected by temperature but Pityogenes chalcographus (L.) showed regional differences $(p<0.05)$. Among the non-bark beetles, the buprestid P. cyanea, considered an aggressive species, did not respond to temperature.

The non-aggressive bark beetles did not significantly correlate with temperature but tended to be more abundant at high temperatures (Figure $1 b ; p=0.20$ ). Among the nonbark beetles the abundant weevil P. pini, considered a non-aggressive species, showed a significant negative relationship with temperature (Figure $1 \mathrm{bb} ; p<0.01$ ) and revealed the same pattern as most aggressive bark beetles.

The natural enemies of bark beetles showed a pattern that often differed from that of the phloem feeders. The total density of natural enemies, i.e., all predatory and parasitoid groups combined, increased with higher temperatures at lower elevations (Figure 1c; $p<0.05)$. On average, their density at the highest sites was $57 \%$ of that at the lowest elevations. Among the predators, the two most abundant families, i.e., the dolichopodid and lonchaeid flies (Diptera) showed opposite trends in their response to temperature (Figure 1cc). The clerid beetles (Coleoptera), represented by the species Thanasimus formicarius (L.), were significantly more abundant at the cooler higher elevation sites (Figure 1cc; $p<0.01$ ).

Among the parasitoids, the hymenopterous Braconidae and Pteromalidae were most abundant (Table S2). These two taxa consistently increased in density with higher temperatures at the lower elevations (Figure $1 c ; p<0.01$ ). The pteromalid density also differed between regions $(p<0.05)$. As a consequence, total parasitoid density also increased with temperature, while total predator density was independent of temperature, due to the contrasting patterns of the dipteran and coleopteran taxa. 

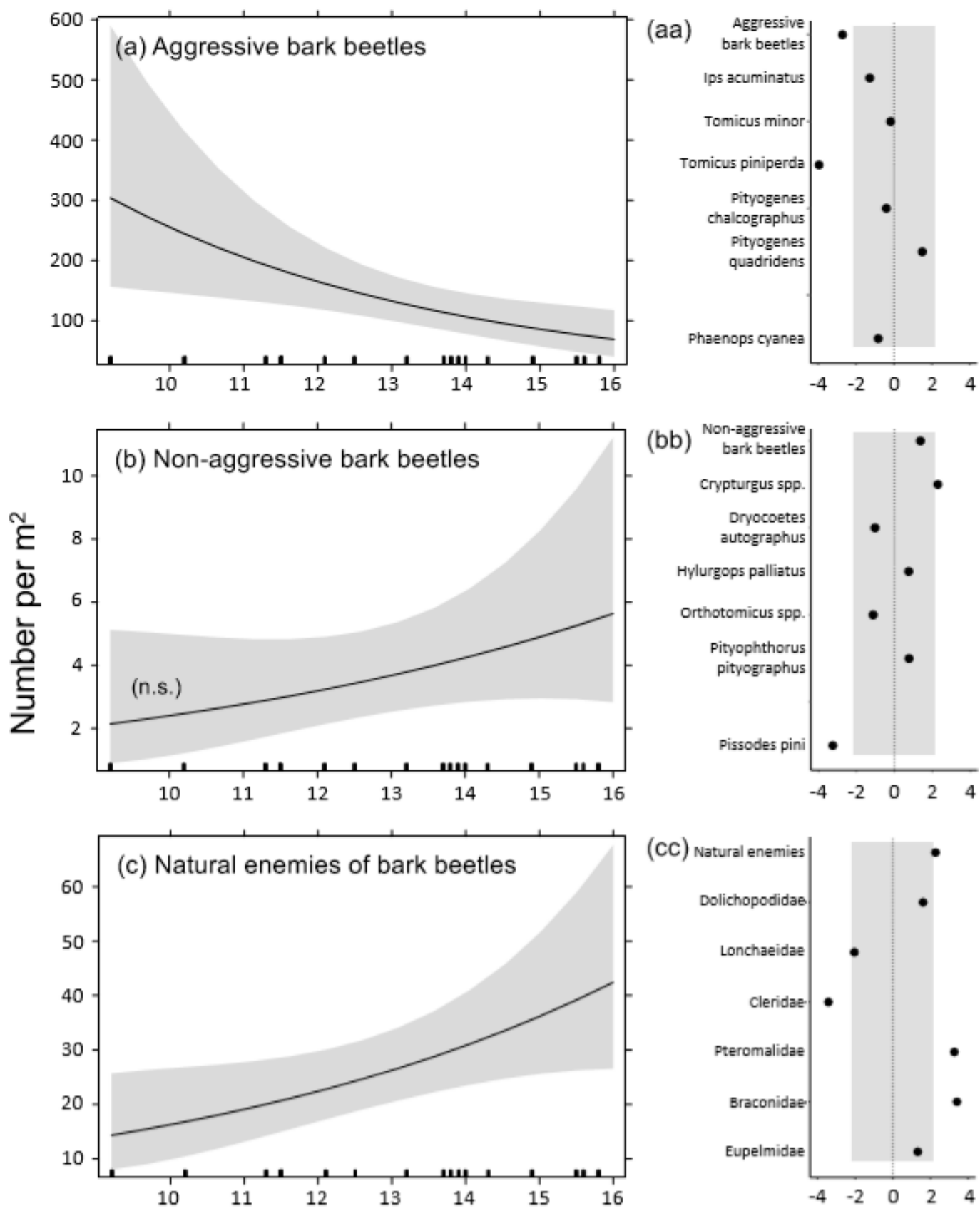

\section{Mean summer temperature $\left({ }^{\circ} \mathrm{C}\right)$}

Figure 1. Relationships between mean summer temperatures and densities of (a) aggressive bark beetles and the buprestid P. cyanea, (b) non-aggressive bark beetles and the weevil P. pini, and (c) and natural enemies of bark beetles at different elevations as well as $t$-values (aa-cc). Negative $t$-values indicate negative association with temperature, and vice versa; the shaded areas indicate the $95 \%$ confidence bands $(\mathbf{a}-\mathbf{c})$ and the non-significant range (aa-cc) $(p \geq 0.05)$. The rug plots at the bottom of the graphs show the values measured in this study. Statistical details are given in Table S1.

Although the numerical ratio of natural enemies to bark beetles increased with higher temperatures $(p<0.001)$, bark beetle mortality imposed by natural enemies showed no significant change with temperature (Figure $2 \mathrm{a} ; p=0.10$ ). This was the consequence of contrasting effects of predators and parasitoids. Mortality by predators averaged $44 \%$ and decreased with increasing temperature (Figure $2 \mathrm{~b} ; p<0.05$ ), while that by parasitoids (average $=9 \%$ ) significantly increased (Figure 2c; $p<0.01$ ), with different slopes depending 
on the region (Table S1). In addition, total mortality significantly increased with increasing species richness of the natural enemies (Figure $3 ; p<0.05$ ).

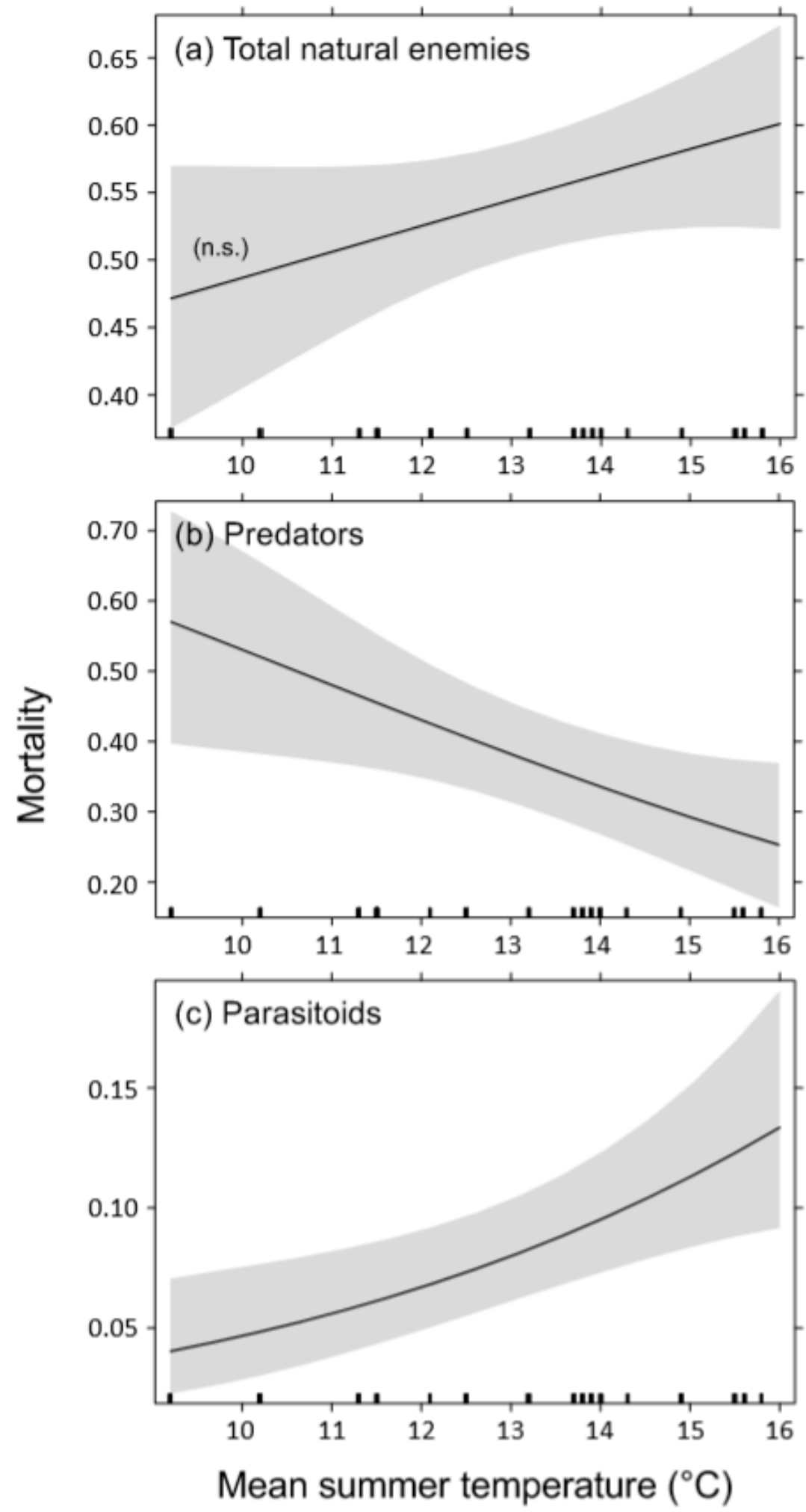

Figure 2. Relationships between mean summer temperatures and bark beetle mortality inflicted by (a) total natural enemies, (b) predators, and (c) parasitoids. The shaded areas indicate the $95 \%$ confidence bands. The rug plots at the bottom of the graphs show the values measured in this study. Statistical details are given in Table S1. 


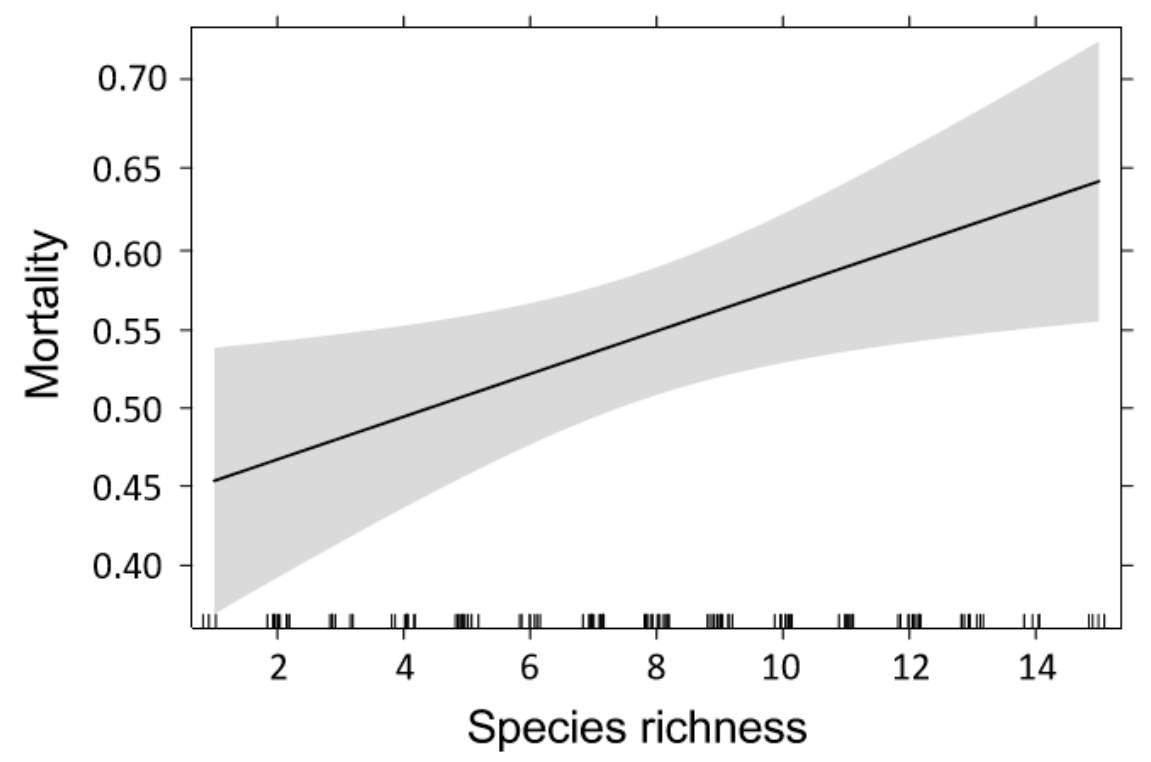

Figure 3. Relationship between total natural enemy species richness and bark beetle mortality. The shaded area indicates the $95 \%$ onfidence band. The rug plots at the bottom of the graph show the values measured in this study. Statistical details are given in Table S1.

\subsection{Resin Flow}

The exudation of resin from living Scots pine trees varied with temperatures (Figure 4; $p<0.05$ ). The amount of resin collected in $24 \mathrm{~h}$ was on average $66 \%$ larger at the low elevations than at the higher sites. It also depended on the region and the samplers' exposition on the stem $(p<0.05)$. The resin duct densities in the outer phloem $(p=0.91)$, inner phloem $(p=0.81)$, and xylem $(p=0.66)$ did not differ between the two elevations and was independent of region and stem exposition (Figure S3).

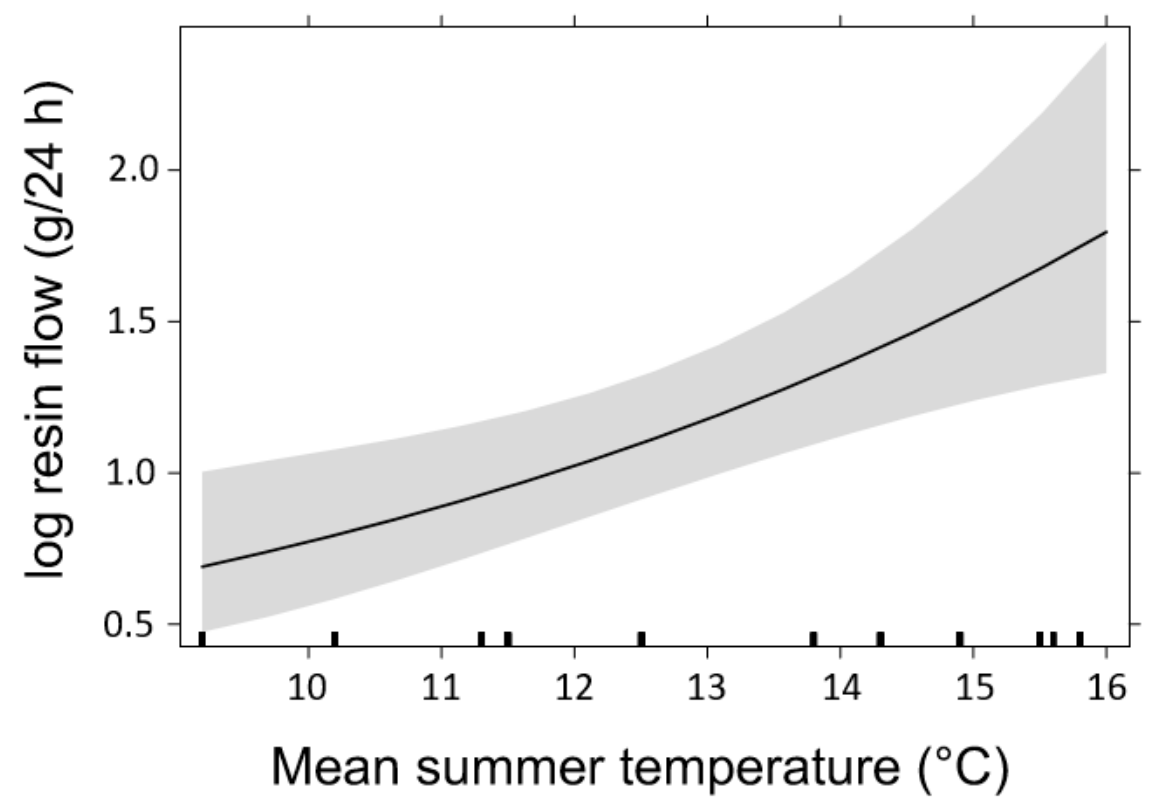

Figure 4. Relationship between resin flow and mean summer temperatures. The shaded area indicates the $95 \%$ confidence band. The rug plot at the bottom of the graph shows the values measured in this study. Statistical details are given in Table S1.

\section{Discussion}

This is one of the first studies on the effects of temperature on a multitrophic interaction between host trees, phloem feeders, and their natural enemies using elevation gradients. 
Elevation gradients are widely acknowledged to serve as a surrogate for temperature effects due to climate change (e.g., [39,40,54,55]). Compared to controlled environmental experiments, this approach is particularly appropriate to assess global warming effects on multitrophic systems under natural conditions.

In our study, we found differentiated responses of bark beetles to the changing temperatures along the gradients. The same is true for the relationship between temperature and bark beetle mortality by natural enemies. Furthermore, we found higher resin defense at higher temperatures. In the following, we relate these findings to our hypotheses and discuss them in the light of potential direct and indirect climate change effects on these trophic interactions.

\subsection{Effects of Temperature on Bark Beetle Populations}

We hypothesized that bark beetle density increases with increasing temperatures at lower elevations. In contrast to this hypothesis (i), the density of aggressive bark beetles, in particular T. piniperda and I. acuminatus, decreased with increasing temperature while that of the non-aggressive species remained largely unaffected (Figure 1). This may be linked to the fact that along elevation not only temperature changes but also precipitation. Due to increased precipitation levels at higher elevations [56], thickness and quality of the host tree phloem increases [57] which is favorable to bark beetles [58,59]. However, only aggressive species that had co-evolved with their host trees can presumably cope with higher contents of toxic monoterpenes. The more susceptible non-aggressive species are limited by defensive compounds in the phloem. These trends were also reported from other gradient studies with bark beetles in pine forests $[60,61]$, while in spruce plantations, non-aggressive species were found to increase with higher temperatures [62]. Interestingly, in a survey of bark beetles in spruce forests, aggressive and non-aggressive species showed contrasting patterns, as in our study, but with direction of the trends reversed [63]. Likewise, in pine forests with Ips confusus (LeConte) infestations, more bark beetle damage occurred at high elevations [64], while that by I. typographus (L.) in spruce forests was more widespread at lower elevations [65]. The higher infestations in lowelevation spruce forests can be largely attributed to the drought susceptibility of the often artificially established plantations in Europe. In addition, methodological differences exist between the studies; Chinellato et al. [63], for instance, recorded maternal galleries $/ \mathrm{m}^{2}$, thus disregarding larval mortality. However, there are also studies from pine forests that demonstrated higher tree mortality at lower elevations $[60,66]$. The contradicting results among studies analyzing bark beetle densities and infestation damage strongly suggest that infestation of forests by bark beetles depends not only on bark beetle infestation pressure (i.e., density), but also, in a critical way, on the current susceptibility of the host trees (bottom-up forces). This may markedly vary between years and with elevation.

The effect of elevation on insect herbivory on leaves and needles has been reported to be likewise heterogeneous (for reviews, see [54,67]). Generally, the density of these insects and their herbivory, particularly on tree host species, are thought to decrease at higher elevations because of temperature constraints on herbivore development and reproduction [67-69]. However, in several studies, the opposite pattern or an intermediate optimum elevation for density and herbivory have been reported [70-72]. These discrepancies in phloeophagous as well as phyllophagous species emphasize the decisive role of host plant susceptibility as affected by e.g., water supply [54] and potentially of natural enemies [14] for herbivores in general.

\subsection{Effects of Temperature on Bark Beetle Mortality}

Total species number and density of total natural enemies were higher at warmer temperatures, but the abundance of some predators decreased with higher temperatures at the lower elevations. Among the Diptera, there seems to be a niche separation in that the Lonchaeidae were more numerous at cooler temperatures, while the Dolichopodidae, like the coleopteran predators, preferred the warmer temperatures at the lower sites. 
Unlike the predators, parasitoids were found to increase with higher temperatures. In hypothesis (ii), we postulated bark beetle mortality by natural enemies to increase with higher temperatures. The density patterns of natural enemies found in our study is also reflected in the bark beetle mortality. Mortality clearly depended on the type of natural enemies, with mortality by predators decreasing and that by parasitoids increasing with higher temperatures (Figure 2).

The decreasing mortality by predators is probably an effect of the functional response of predators consuming more prey per capita at higher prey densities [73,74]. However, the different predatory groups responded heterogeneously. Such divergence has also been reported from coleopteran predators of bark beetles in North American pine forests [75]. In a similar study in the Greater Yellowstone Ecosystem, the response of the predatory beetle T. undatulus (Say) remained unclear and differed between years [43].

Elevation gradient studies in general showed, that non-bark-beetle predators can exhibit quite heterogeneous distributions [76-78]. We suggest this is due to the fact that predators, in contrast to parasitoids, have very diverse lifestyles and can switch between numerous prey species. In addition, the contrasting responses of predators to elevation reported in the literature are significantly influenced by scale. The investigated gradients have covered extremely different ranges, from $200 \mathrm{~m} \mathrm{[43]} \mathrm{to} 4000 \mathrm{~m} \mathrm{[77],} \mathrm{thereby} \mathrm{including}$ different habitats with different types of prey (e.g., subcortical, free-feeding, grounddwelling species). In our study, we strived towards selecting sites with comparable tree species composition and forest structure in each gradient, even if this was not possible in all cases (cf. Table 1). Thus, we cannot completely exclude that our results on predators are partly influenced by differences in forest structure.

Parasitoid abundance in general seems to be largely driven by temperature, since a negative relationship between parasitoid density and elevation seems to be consistent across studies. In a meta-analysis, parasitoid species richness and parasitism were generally found to be higher at low elevations with warmer conditions [39]. This was particularly true for ectoparasitoids, such as most of the bark beetle parasitoids found in our study [44]. Thus, the ongoing climate warming has not or not yet caused a noticeable phenological disruption of hosts and parasitoids in our case. Instead, the higher temperature at low elevations promoted parasitism. Moreover, parasitoid activity may be limited at higher elevations due to stronger winds, more frequent precipitation and mist [79].

Our approach of calculating mortality rates does not reflect accurate bark beetle mortality but provides valid estimates. In our study, natural enemies caused an estimated $50 \%$ mortality to bark beetles (cf. Figure 3). This stresses their importance in downregulating bark beetle populations in endemic situations. Predators were found to be much more important natural enemies of bark beetles than parasitoids. Although they occurred in lower densities, they consumed several prey per capita and thus caused, on average, $44 \%$ bark beetle mortality. The more abundant parasitoids, killing just one host per capita, eliminated only $9 \%$ of the bark beetle broods. As bark beetle mortality by predators was negatively related to increasing temperature (i.e., less mortality at lower elevations), the predators' impact on bark beetles is likely to decrease under a warming climate.

\subsection{Effects of Temperature on Host Tree Defense}

In agreement with hypothesis (iii), defensive resin flow of the host trees increased with warmer temperatures at lower elevations. This is in line with previous studies that reported not only the amount of resin, but also the concentration of resin monoterpenes in certain Pinus species to be positively linked to lower elevations [41]. The infestation success of bark beetles in living conifers very much depends on how well the trees can defend against insect attack attempts. Conifers can do so by exuding resin, which contains various terpenoids that are, in high concentrations, toxic to bark beetles [12,80]. In pine, preformed (constitutive) pressurized resin is stored in mostly radial ducts in the phloem and xylem. This serves as a first defense level before, upon insect or fungal attack, additional resin is formed [81-83]. We measured the resin flow over $24 \mathrm{~h}$. This resin was probably 
constituted from both constitutive and induced resin, as the neosynthesis of resin can occur immediately after attack or wounding [12]. Our results thus suggest a better defense against intruders at higher temperatures, providing sufficient water supply.

In principle, the increased resin exudation of trees at the lower sites could be due either to reduced resin viscosity at higher temperatures or to a local adaption of the density or size of resin ducts. Resin duct density is known to respond to environmental factors [84,85]. We found that duct density in the phloem and xylem did not differ between elevations. Therefore, the higher resin exudation upon mechanical wounding or bark beetle penetration at lower elevations is probably simply a physical effect of reduced resin viscosity under higher temperatures [86]. The growth-defense tradeoff theory states that plants growing at higher elevations with lower temperatures are limited in productivity and therefore direct more resources into defense [17]. In the case of resin defense of conifers, this phenomenon may be masked by physical effects of viscosity.

\section{Conclusions}

Our study provides important empirical data for our understanding of the complex interactions between trophic levels, which serves as a basis for simulation models of tree mortality and forest dynamics, a gap that has recently been identified [31,42,87]. We have shown that, under endemic conditions, the density of aggressive bark beetles decreased with warmer conditions, while parasitism and defensive resin flow of the host trees increased. From this, it might be concluded that global warming will reduce future infestation risks. However, recent large-scale outbreaks of bark beetles worldwidelargely due to drought stress-have demonstrated that the opposite trend is occurring (e.g., [88-91]). This strongly suggests that the negative effects of increasing temperature on bark beetles mentioned above are overruled by increased drought stress, resulting in higher susceptibility of the host trees [92]. Moreover, higher temperatures in the future are likely to increase yearly number of bark beetle generations (e.g., [25]), reduce their predator-mediated mortality (this study), and potentially disrupt phenological synchrony of hosts and parasitoids $[14,27,93]$. Further, hotter droughts and other disturbances will compromise host tree resistance [21]. These complex interactions depend on numerous site- and environment-specific conditions and more field studies on multitrophic systems are needed to reveal general, overarching patterns.

Supplementary Materials: The following are available online at https:/ /www.mdpi.com/1999-490 7/12/2/136/s1, Figure S1: Photoeclectors for log incubation, Figure S2: Thin section of Scots pine wood, Table S1: Statistical output, Table S2: Densities of emerged insects, Figure S3: Relationship temperature-resin duct density.

Author Contributions: Conceptualization, B.W. and A.R.; methodology, B.W. and A.R.; formal analysis, M.M.G.; investigation, B.W., D.S.M. and M.K.; data curation, B.W.; Writing-Original draft preparation, B.W. and M.M.G.; Writing-Review and editing, all authors; visualization, M.M.G. and B.W.; project administration, B.W.; funding acquisition, B.W. and A.R. All authors have read and agreed to the published version of the manuscript.

Funding: This research was funded by the EU Interreg Program Alcotra, the Italian Regione Autonoma Valle d'Aosta, and the Swiss Cantons Valais and Grisons.

Institutional Review Board Statement: Not applicable.

Informed Consent Statement: Not applicable.

Data Availability Statement: The underlying data set is available at www.envidat.ch, doi 10.16904/envidat.86.

Acknowledgments: We are very grateful to many collaborators during the extensive work in the field and in the lab: D. Bösch, A. Gall, M. Gees, B. Kinigadner, S. Mathis, Q. Kupper, M. Schmidheiny, D. Steiner, A. Streit, D. Trummer, and O. Zuberbühler. The effective cooperation with the local forest services from Aosta Valley (Italy), Visp and Salgesch (Valais), and Scharans and Felsberg (Grisons) is very much appreciated. We also acknowledge the important work of further insect identifications by 
K. van Achterberg, P. Duelli, I. MacGowan, M. Neumann and M. Pollet. The different subprojects were funded by the EU Interreg Program Alcotra, the Italian Regione Autonoma Valle d'Aosta and the Swiss Cantons Valais and Grisons. M. Dawes kindly provided editing assistance for the paper.

Conflicts of Interest: The authors declare no conflict of interest. The funders had no role in the design of the study; in the collection, analyses, or interpretation of data; in the writing of the manuscript, or in the decision to publish the results.

\section{References}

1. Allen, C.D.; Macalady, A.K.; Chenchouni, H.; Bachelet, D.; McDowell, N.; Vennetier, M.; Kitzberger, T.; Rigling, A.; Breshears, D.D.; Hogg, E.H.; et al. A global overview of drought and heat-induced tree mortality reveals emerging climate change risks for forests. For. Ecol. Manag. 2010, 259, 660-684. [CrossRef]

2. Allen, C.D.; Breshears, D.D.; McDowell, N.G. On underestimation of global vulnerability to tree mortality and forest die-off from hotter drought in the Anthropocene. Ecosphere 2015, 6, 129. [CrossRef]

3. Young, D.J.N.; Stevens, J.T.; Earles, J.M.; Moore, J.; Ellis, A.; Jirka, A.L.; Latimer, A.M. Long-term climate and competition explain forest mortality patterns under extreme drought. Ecol. Lett. 2017, 20, 78-86. [CrossRef] [PubMed]

4. McDowell, N.; Pockman, W.T.; Allen, C.D.; Breshears, D.D.; Cobb, N.; Kolb, T.; Plaut, J.; Sperry, J.; West, A.; Williams, D.G. Mechanisms of plant survival and mortality during drought: Why do some plants survive while others succumb to drought? New Phytol. 2008, 178, 719-739. [CrossRef]

5. Seidl, R.; Schelhaas, M.J.; Rammer, W.; Verkerk, P.J. Increasing forest disturbances in Europe and their impact on carbon storage. Nat. Clim. Chang. 2014, 4, 806-810. [CrossRef] [PubMed]

6. Anderegg, W.R.L.; Hicke, J.A.; Fisher, R.A.; Allen, C.D.; Aukema, J.; Bentz, B.; Hood, S.; Lichstein, J.W.; Macalady, A.K.; McDowell, N.; et al. Tree mortality from drought, insects, and their interactions in a changing climate. New Phytol. 2015, 208, 674-683. [CrossRef]

7. Rosenberger, D.W.; Venette, R.C.; Aukema, B.H. Development of an aggressive bark beetle on novel hosts: Implications for outbreaks in an invaded range. J. Appl. Ecol. 2018, 55, 1526-1537. [CrossRef]

8. Bentz, B.J.; Jönsson, A.M.; Schroeder, M.; Weed, A.; Wilcke, R.A.I.; Larsson, K. Ips typographus and Dendroctonus ponderosae models project thermal suitability for intra- and inter-continental establishment in a changing climate. Front. For. Glob. Change $2019,2,1$. [CrossRef]

9. Wermelinger, B. Ecology and management of the spruce bark beetle Ips typographus-A review of recent research. For. Ecol. Manag. 2004, 202, 67-82. [CrossRef]

10. Seidl, R.; Rammer, W. Climate change amplifies the interactions between wind and bark beetle disturbances in forest landscapes. Landsc. Ecol. 2017, 32, 1485-1498. [CrossRef]

11. Paine, T.D.; Raffa, K.F.; Harrington, T.C. Interactions among scolytid bark beetles, their associated fungi, and live host conifers. Annu. Rev. Entomol. 1997, 42, 179-206. [CrossRef]

12. Krokene, P. Conifer defense and resistance to bark beetles. In Bark Beetles: Biology and Ecology of Native and Invasive Species; Vega, F.E., Hofstetter, R.W., Eds.; Academic Press: London, UK, 2015; pp. 177-207.

13. Raffa, K.F.; Grégoire, J.C.; Lindgren, B.S. Natural history and ecology of bark beetles. In Bark Beetles: Biology and Ecology of Native and Invasive Species; Vega, F.E., Hofstetter, R.W., Eds.; Academic Press: London, UK, 2015; pp. 1-40.

14. Damien, M.; Tougeron, K. Prey-predator phenological mismatch under climate change. Curr. Opin. Ins. Sci. 2019, 35, 60-68. [CrossRef]

15. Huang, J.B.; Kautz, M.; Trowbridge, A.M.; Hammerbacher, A.; Raffa, K.F.; Adams, H.D.; Goodsman, D.W.; Xu, C.G.; Meddens, A.J.H.; Kandasamy, D.; et al. Tree defence and bark beetles in a drying world: Carbon partitioning, functioning and modelling. New Phytol. 2020, 225, 26-36. [CrossRef]

16. Coley, P.D.; Bryant, J.P.; Chapin, F.S.I. Resource availability and plant antiherbivore defense. Science 1985, 230, 895-899. [CrossRef]

17. Huot, B.; Yao, J.; Montgomery, B.; He, S. Growth-defense tradeoffs in plants: A balancing act to optimize fitness. Mol. Plant 2014, 7, 1267-1287. [CrossRef]

18. Boege, K.; Barton, K.E.; Dirzo, R. Influence of tree ontogeny on plant-herbivore interactions. In Size-and Age-Related Changes in Tree Structure and Function; Meinzer, F.C., Lachenbruch, B., Dawson, T.E., Eds.; Springer: Amsterdam, The Netherlands, 2011; pp. 193-214.

19. Ferrenberg, S.; Kane, J.M.; Langenhan, J.M. To grow or defend? Pine seedlings grow less but induce more defences when a key resource is limited. Tree Physiol. 2015, 35, 107-111. [CrossRef]

20. Gaylord, M.L.; Kolb, T.E.; Pockman, W.T.; Plaut, J.A.; Yepez, E.A.; Macalady, A.K.; Pangle, R.E.; McDowell, N.G. Drought predisposes piñon-juniper woodlands to insect attacks and mortality. New Phytol. 2013, 198, 567-578. [CrossRef]

21. Netherer, S.; Matthews, B.; Katzensteiner, K.; Blackwell, E.; Henschke, P.; Hietz, P.; Pennerstorfer, J.; Rosner, S.; Kikuta, S.; Schume, H. Do water-limiting conditions predispose Norway spruce to bark beetle attack? New Phytol. 2015, 205, 1128-1141. [CrossRef]

22. Mulock, P.; Christiansen, E. The threshold of successful attack by Ips typographus on Picea abies: A field experiment. For. Ecol. Manag. 1986, 14, 125-132. [CrossRef]

23. Nelson, W.A.; Lewis, M.A. Connecting host physiology to host resistance in the conifer-bark beetle system. Theor. Ecol. 2008, 1, 163-177. [CrossRef] 
24. Ayres, M.P.; Lombardero, M.J. Assessing the consequences of global change for forest disturbance from herbivores and pathogens. Sci. Total Environ. 2000, 262, 263-286. [CrossRef]

25. Jakoby, O.; Lischke, H.; Wermelinger, B. Climate change alters elevational phenology patterns of the European spruce bark beetle (Ips typographus). Glob. Change Biol. 2019, 25, 4048-4063. [CrossRef]

26. Jönsson, A.M.; Harding, S.; Krokene, P.; Lange, H.; Lindelöw, A.; Økland, B.; Ravn, H.P.; Schroeder, L.M. Modelling the potential impact of global warming on Ips typographus voltinism and reproductive diapause. Clim. Chang. 2011, 109, 695-718. [CrossRef]

27. Parmesan, C. Ecological and evolutionary responses to recent climate change. Ann. Rev. Ecol. Evol. Syst. 2006, 37, 637-669. [CrossRef]

28. Raffa, K.F.; Aukema, B.H.; Bentz, B.J.; Carroll, A.L.; Hicke, J.A.; Kolb, T.E. Responses of tree-killing bark beetles to a changing climate. In Climate Change and Insect Pests; Björkman, C., Niemelä, P., Eds.; CAB International: Oxfordshire, UK, 2015 ; pp. 173-201.

29. Wermelinger, B.; Seifert, M. Temperature-dependent reproduction of the spruce bark beetle Ips typographus, and analysis of the potential population growth. Ecol. Entomol. 1999, 24, 103-110. [CrossRef]

30. Hance, T.; van Baaren, J.; Vernon, P.; Boivin, G. Impact of extreme temperatures on parasitoids in a climate change perspective. Annu. Rev. Entomol. 2007, 52, 107-126. [CrossRef]

31. Jactel, H.; Koricheva, J.; Castagneyrol, B. Responses of forest insect pests to climate change: Not so simple. Curr. Opin. Insect Sci. 2019, 35, 103-108. [CrossRef]

32. Weber, P.; Bugmann, H.; Rigling, A. Radial growth responses to drought of Pinus sylvestris and Quercus pubescens in an inner-Alpine dry valley. J. Veg. Sci. 2007, 18, 777-792. [CrossRef]

33. Williams, A.P.; Allen, C.D.; Macalady, A.K.; Griffin, D.; Woodhouse, C.A.; Meko, D.M.; Swetnam, T.W.; Rauscher, S.A.; Seager, R.; Grissino-Mayer, H.D.; et al. Temperature as a potent driver of regional forest drought stress and tree mortality. Nat. Clim. Chang. 2013, 3, 292-297. [CrossRef]

34. Štefková, K.; Okrouhlík, J.; Doležal, P. Development and survival of the spruce bark beetle, Ips typographus (Coleoptera: Curculionidae: Scolytinae) at low temperatures in the laboratory and the field. Eur. J. Entomol. 2017, 114, 1-6. [CrossRef]

35. Henn, M.W.; Schopf, R. Response of beech (Fagus sylvatica) to elevated $\mathrm{CO}_{2}$ and N: Influence on larval performance of the gypsy moth Lymantria dispar (Lep., Lymantriidae). J. Appl. Entomol. 2001, 125, 501-505. [CrossRef]

36. Stiling, P.; Cornelissen, T. How does elevated carbon dioxide $\left(\mathrm{CO}_{2}\right)$ affect plant-herbivore interactions? A field experiment and meta-analysis of $\mathrm{CO}_{2}$-mediated changes on plant chemistry and herbivore performance. Glob. Chang. Biol. 2007, 13, 1823-1842. [CrossRef]

37. Körner, C.; Asshoff, R.; Bignucolo, O.; Hättenschwiler, S.; Keel, S.G.; Peláez-Riedl, S.; Pepin, S.; Siegwolf, R.T.W.; Zotz, G. Carbon flux and growth in mature deciduous forest trees exposed to elevated $\mathrm{CO}_{2}$. Science 2005, 309, 1360-1362. [CrossRef]

38. Novick, K.A.; Katul, G.G.; McCarthy, H.R.; Oren, R. Increased resin flow in mature pine trees growing under elevated $\mathrm{CO}_{2}$ and moderate soil fertility. Tree Physiol. 2012, 32, 752-763. [CrossRef] [PubMed]

39. Péré, C.; Jactel, H.; Kenis, M. Response of insect parasitism to elevation depends on host and parasitoid life-history strategies. Biol. Lett. 2013, 9. [CrossRef]

40. Rasmann, S.; Pellissier, L.; Defossez, E.; Jactel, H.; Kunstler, G. Climate-driven change in plant-insect interactions along elevation gradients. Funct. Ecol. 2014, 28, 46-54. [CrossRef]

41. Ferrenberg, S.; Langenhan, J.M.; Loskot, S.A.; Rozal, L.M.; Mitton, J.B. Resin monoterpene defenses decline within three widespread species of pine (Pinus) along a 1530-m elevational gradient. Ecosphere 2017, 8, e01975. [CrossRef]

42. Moreira, X.; Petry, W.K.; Mooney, K.A.; Rasmann, S.; Abdala-Roberts, L. Elevational gradients in plant defences and insect herbivory: Recent advances in the field and prospects for future research. Ecography 2018, 41, 1485-1496. [CrossRef]

43. Krause, A.M.; Townsend, P.A.; Lee, Y.; Raffa, K.F. Predators and competitors of the mountain pine beetle Dendroctonus ponderosae (Coleoptera: Curculionidae) in stands of changing forest composition associated with elevation. Agric. For. Entomol. 2017, 20, 402-413. [CrossRef]

44. Kenis, M.; Wermelinger, B.; Grégoire, J.C. Research on parasitoids and predators of Scolytidae-A review. In Bark and Wood Boring Insects in Living Trees in Europe-A synthesis; Lieutier, F., Day, K.R., Battisti, A., Grégoire, J.C., Evans, H.F., Eds.; Kluwer Academic Publishers: Dordrecht, The Netherlands, 2004; pp. 237-290.

45. Wermelinger, B.; Rigling, A.; Schneider Mathis, D.; Dobbertin, M. Assessing the role of bark- and wood-boring insects in the decline of Scots pine (Pinus sylvestris) in the Swiss Rhone valley. Ecol. Entomol. 2008, 33, 239-249. [CrossRef]

46. Karsky, D.; Strom, B.; Thistle, H. An Improved Method for Collecting and Monitoring Pine Oleoresin; US Department of Agriculture, USDA Forest Service, Technology and Development: Missoula, MT, USA, 2004.

47. Gärtner, H.; Heinrich, I. The formation of traumatic rows of resin ducts in Larix decidua and Picea abies (Pinaceae) as a result of wounding experiments in the dormant season. IAWA J. 2009, 30, 199-215. [CrossRef]

48. R Core Team. R: A Language and Environment for Statistical Computing, Version 3.6.0. Available online: https://www.R-project. org (accessed on 10 August 2020).

49. Pinheiro, J.C.; Bates, D.M.; DebRoy, S.; Sarkar, D.; R Core Team. Nlme: Linear and Nonlinear Mixed Effects Models. R Package Version 3.1-139. Available online: http:/ /CRAN.R-project.org/package=nlme (accessed on 10 August 2020).

50. Bates, D.; Maechler, M.; Bolker, B.; Walker, S. Fitting linear mixed-effects models using lme4. J. Stat. Software 2015, 67, 1-48. [CrossRef] 
51. Brooks, M.E.; Kristensen, K.; van Benthem, K.J.; Magnusson, A.; Berg, C.W.; Nielsen, A.; Skaug, H.J.; Maechler, M.; Bolker, B.M. glmmTMB balances speed and flexibility among packages for zero-inflated generalized linear mixed modeling. $R J$. 2017, 9, 378-400. [CrossRef]

52. Fox, J.; Weisberg, S. An \{R\} Companion to Applied Regression, 3rd ed.; SAGE: Thousand Oaks, CA, USA, 2019.

53. Fox, J. Effect displays in R for generalised linear models. J. Stat. Softw. 2003, 8, 1-27. [CrossRef]

54. Hodkinson, I.D. Terrestrial insects along elevation gradients: Species and community responses to altitude. Biol. Rev. 2005, 80, 489-513. [CrossRef]

55. Leingärtner, A.; Hoiss, B.; Krauss, J.; Steffan-Dewenter, I. Combined effects of extreme climatic events and elevation on nutritional quality and herbivory of alpine plants. PLOS ONE 2014, 9. [CrossRef]

56. Sevruk, B. Regional dependency of precipitation-altitude relationship in the Swiss Alps. Clim. Chang. 1997, 36, 355-369. [CrossRef]

57. Lahr, E.C.; Sala, A. Species, elevation, and diameter affect whitebark pine and lodgepole pine stored resources in the sapwood and phloem: Implications for bark beetle outbreaks. Can. J. For. Res. 2014, 44, 1312-1319. [CrossRef]

58. Amman, G.D. Mountain pine beetle brood production in relation to thickness of lodgepole pine phloem. J. Econ. Entomol. 1972, 65, 138-140. [CrossRef]

59. Boone, C.K.; Aukema, B.H.; Bohlmann, J.; Carroll, A.L.; Raffa, K.F. Efficacy of tree defense physiology varies with bark beetle population density: A basis for positive feedback in eruptive species. Can. J. For. Res. 2011, 41, 1174-1188. [CrossRef]

60. Rubin-Aguirre, A.; Saenz-Romero, C.; Lindig-Cisneros, R.; del-Rio-Mora, A.A.; Tena-Morelos, C.A.; Campos-Bolaños, R.; del-Val, E. Bark beetle pests in an altitudinal gradient of a Mexican managed forest. For. Ecol. Manag. 2015, 343, 73-79. [CrossRef]

61. Soto-Correa, J.C.; Avilés-Carrillo, I.; Giron-Gutiérrez, D.; Cambrón-Sandoval, V.H. Altitudinal abundance of Dendroctonus frontalis (Coleoptera: Curculionidae) in relation to climatic variables in Hidalgo, Mexico. Rev. Biol. Trop. 2019, 67, 370-379. [CrossRef]

62. Williams, D.T.; Cull, T.; Forster, J. Investigating the abundance and flight period of bark beetles (Coleoptera: Curculionidae: Scolytinae) over elevational gradients in Sitka spruce forests. Agric. For. Entomol. 2020. [CrossRef]

63. Chinellato, F.; Faccoli, M.; Marini, L.; Battisti, A. Distribution of Norway spruce bark and wood-boring beetles along Alpine elevational gradients. Agric. For. Entomol. 2014, 16, 111-118. [CrossRef]

64. Kleinman, S.J.; DeGomez, T.E.; Snider, G.B.; Williams, K.E. Large-scale pinyon Ips (Ips confusus) outbreak in southwestern United States tied with elevation and land cover. J. For. 2012, 110, 194-200. [CrossRef]

65. Seidl, R.; Baier, P.; Rammer, W.; Schopf, A.; Lexer, M.J. Modelling tree mortality by bark beetle infestation in Norway spruce forests. Ecol. Model. 2007, 206, 383-399. [CrossRef]

66. Paz-Kagan, T.; Brodrick, P.G.; Vaughn, N.R.; Das, A.J.; Stephenson, N.L.; Nydick, K.R.; Asner, G.P. What mediates tree mortality during drought in the southern Sierra Nevada? Ecol. Appl. 2017, 27, 2443-2457. [CrossRef]

67. Galmán, A.; Abdala-Roberts, L.; Zhang, S.; Berny-Mier y Teran, J.C.; Rasmann, S.; Moreira, X. A global analysis of elevational gradients in leaf herbivory and its underlying drivers: Effects of plant growth form, leaf habit and climatic correlates. J. Ecol. 2018, 106, 413-421. [CrossRef]

68. Sanchez-Rodriguez, J.F.; Baz, A. The effects of elevation on the butterfly communities of a Mediterranean mountain, Sierra de Javalambre, Central Spain. J. Lepidopt. Soc. 1995, 49, 192-207.

69. Röder, J.; Bässler, C.; Brandl, B.; Dvořak, L.; Floren, A.; Gossner, M.M.; Gruppe, A.; Jarzabek-Müller, A.; Vojtech, O.; Wagner, C.; et al. Arthropod species richness in the Norway Spruce (Picea abies (L.) Karst.) canopy along an elevation gradient. For. Ecol. Manag. 2010, 259, 1513-1521. [CrossRef]

70. Reymond, A.; Purcell, J.; Cherix, D.; Guisan, A.; Pellissier, L. Functional diversity decreases with temperature in high elevation ant fauna. Ecol. Entomol. 2013, 38, 364-373. [CrossRef]

71. Altmann, S.H.; Claros, S. Insect abundance and damage on the deciduous Nothofagus macrocarpa increase with altitude at a site in the Mediterranean climate zone of Chile. Austral. Entomol. 2015, 54, 402-410. [CrossRef]

72. Azrag, A.G.A.; Pirk, C.W.W.; Yusuf, A.A.; Pinard, F.; Niassy, S.; Mosomtai, G.; Babin, R. Prediction of insect pest distribution as influenced by elevation: Combining field observations and temperature-dependent development models for the coffee stink bug, Antestiopsis thunbergii (Gmelin). PLoS ONE 2018, 13, e0199569. [CrossRef]

73. Holling, C.S. Some characteristics of simple types of predation and parasitism. Can. Entomol. 1959, 91, 385-398. [CrossRef]

74. Reeve, J.D. Predation and bark beetle dynamics. Oecologia 1997, 112, 48-54. [CrossRef]

75. Williams, K.K.; McMillin, J.D.; DeGomez, T.E. Relative and seasonal abundance of three bark beetle predators (Coleoptera: Trogositidae, Cleridae) across an elevation gradient in ponderosa pine forests of north central Arizona. West. N. Am. Nat. 2009, 69, 351-363. [CrossRef]

76. Corcos, D.; Cerretti, P.; Mei, M.; Taglianti, A.V.; Paniccia, D.; Santoiemma, G.; De Biase, A.; Marini, L. Predator and parasitoid insects along elevational gradients: Role of temperature and habitat diversity. Oecologia 2018, 188, 193-202. [CrossRef]

77. Camacho, L.F.; Aviles, L. Decreasing predator density and activity explains declining predation of insect prey along elevational gradients. Am. Nat. 2019, 194, 334-343. [CrossRef]

78. Libra, M.; Tulai, S.; Novotny, V.; Hrcek, J. Elevational contrast in predation and parasitism risk to caterpillars in a tropical rainforest. Entomol. Exp. Appl. 2019, 167, 922-931. [CrossRef]

79. Fink, U.; Völkl, W. The effect of abiotic factors on foraging and oviposition success of the aphid parasitoid, Aphidius rosae. Oecologia 1995, 103, 371-378. [CrossRef] 
80. Raffa, K.F. Terpenes tell different tales at different scales: Glimpses into the chemical ecology of conifer-bark beetle-microbial interactions. J. Chem. Ecol. 2014, 40, 1-20. [CrossRef]

81. Franceschi, V.R.; Krokene, P.; Christiansen, E.; Krekling, T. Anatomical and chemical defenses of conifer bark against bark beetles and other pests. New Phytol. 2005, 167, 353-376. [CrossRef]

82. DeRose, R.J.; Bekker, M.F.; Long, J.N. Traumatic resin ducts as indicators of bark beetle outbreaks. Can. J. For. Res. 2017, 47, 1168-1174. [CrossRef]

83. Denham, S.O.; Coyle, D.R.; Oishi, A.C.; Bullock, B.P.; Heliövaara, K.; Novick, K.A. Tree resin flow dynamics during an experimentally induced attack by Ips avulsus, I. calligraphus, and I. grandicollis. Can. J. For. Res. 2019, 49, 53-63. [CrossRef]

84. Wimmer, R.; Grabner, M. Effects of climate on vertical resin duct density and radial growth of Norway spruce [Picea abies (L.) Karst.]. Trees 1997, 11, 271-276. [CrossRef]

85. Rigling, A.; Brühlhart, H.; Bräker, O.U.; Forster, T.; Schweingruber, F.H. Effects of irrigation on diameter growth and vertical resin duct production in Pinus sylvestris L. on dry sites in the central Alps, Switzerland. For. Ecol. Manag. 2003, 175, 285-296. [CrossRef]

86. Ruel, J.J.; Ayres, M.P.; Lorio, P.L.J. Loblolly pine responds to mechanical wounding with increased resin flow. Can. J. For. Res. 1998, 28, 596-602. [CrossRef]

87. Gely, C.; Laurance, S.G.W.; Stork, N.E. How do herbivorous insects respond to drought stress in trees? Biol. Rev. 2019. [CrossRef]

88. Marini, L.; Økland, B.; Jönsson, A.M.; Bentz, B.; Carroll, A.; Forster, B.; Grégoire, J.C.; Hurling, R.; Nageleisen, L.M.; Netherer, S.; et al. Climate drivers of bark beetle outbreak dynamics in Norway spruce forests. Ecography 2017, 40, 1426-1435. [CrossRef]

89. Mezei, P.; Jakuš, R.; Pennerstorfer, J.; Havašová, M.; Škvarenina, J.; Ferenčík, J.; Slivinský, J.; Bičárová, S.; Bilčík, D.; Blaženec, M.; et al. Storms, temperature maxima and the Eurasian spruce bark beetle Ips typographus-An infernal trio in Norway spruce forests of the Central European High Tatra Mountains. Agric. For. Meteorol. 2017, 242, 85-95. [CrossRef]

90. Seybold, S.J.; Bentz, B.J.; Fettig, C.J.; Lundquist, J.E.; Progar, R.A.; Gillette, N.E. Management of western North American bark beetles with semiochemicals. Annu. Rev. Entomol. 2018, 63, 407-432. [CrossRef] [PubMed]

91. Hlásny, T.; Krokene, P.; Liebhold, A.; Montagné-Huck, C.; Müller, J.; Qin, H.; Raffa, K.; Schelhaas, M.J.; Seidl, R.; Svoboda, M.; et al. From Science to Policy 8: Living with Bark Beetles: Impacts, Outlook and Management Options; European Forest Institute: Joensuu, Finland, 2019.

92. Rouault, G.; Candau, J.N.; Lieutier, F.; Nageleisen, L.M.; Martin, J.C.; Warzee, N. Effects of drought and heat on forest insect populations in relation to the 2003 drought in Western Europe. Ann. For. Sci. 2006, 63, 613-624. [CrossRef]

93. Wetherington, M.T.; Jennings, D.E.; Shrewsbury, P.M.; Duan, J.J. Climate variation alters the synchrony of host-parasitoid interactions. Ecol. Evol. 2017, 7, 8578-8587. [CrossRef] [PubMed] 